\title{
The Importance of Microorganisms and Their Effects on Medicinal Plants and Their Various Applications
}

\author{
Abdlmanam Fakron ${ }^{1}$, Idress Hamad Attitalla ${ }^{1,2^{*}}$, Mohamed Younes A Hassan ${ }^{3}$ and Sumeet Dwivedi ${ }^{4}$ \\ ${ }^{1}$ Department of Microbiology, Faculty of Science, Omar Al-Mukhtar University, Libya \\ ${ }^{2}$ Department of Lab Medicine, Faculty of Medical Technology, Omar Al-Mukhtar University, Libya \\ ${ }^{3}$ PhD Researcher, Chemist and Director of Occupational Safety and Health Administration, Minya Company \\ for Drinking Water and Sanitation, Al-Azhar University, Elminia, Egypt \\ ${ }^{4}$ Department of Pharmacognosy, Faculty of Pharmacy, Oriental University, Indore, India \\ *Corresponding author: Idress Hamad Attitalla, Professor, Department of Microbiology, Faculty of Science and Dean, \\ Faculty of Medical Technology, Omar Al-Mukhtar University, Box 919, Al-Bayda, Libya, Tel: +218-917-133-903
}

\begin{abstract}
Since photosynthesis is the primary process through which light energy absorbed and converted into organic matter, thus, plant chlorophyll pigment (forms $A$ and $B$ ) plays an essential role in the progression absorbed solar energy and synthesis of organic matter in a plant. Therefore, this paper aims at the extent to which the optical activity of chlorophyll molecules monitored and methods (non-destructive and destructive) for quantification of chlorophyll content in plants. These methods using to estimate the effect of different stress factors (abiotic, biotic, and xenobiotic) on the efficiency of photosynthesis and bio-productivity on the yield of different varieties. Besides, these methods used to analyze the visual activity of chlorophyll and/or as well as to evaluate the interaction of weed species with different agricultural practices (mineral nutrition, herbicide treatment, etc.), in addition to studying various aspects of the environmental physiology of weeds and their effect on crop harvesting. Drought stress is one of the most important factors affecting plant growth. Plant growth under drought stress can promote applying microbial pollination, such as using plant growth-promoting roots bacteria. This research carried as a factorial experiment in a completely randomized design.

The first step involved bio-fertilizer (A) and control (without bio-fertilizers). The results indicated that the level of treated bacterial inoculation had the highest effect in increasing photosynthetic pigments $(p<0.01)$. While the lowest amount of photosynthetic dyes were recorded under treatment A. Highest and lowest shoot fresh. Weight belonged to the coefficients respectively $(p<0.01)$. The results indicated that using the bio-fertilizer separately had a more positive effect on nutrient absorption than Juniperus phoenicea.
\end{abstract}

Overall, the results indicate that growth-promoting bacteria such as bio-fertilizers have a greater effect on growth, photosynthetic pigments, and nutrient absorption than Juniperus phoenicea. Using a microbial inoculation in agriculture increases plant productivity and resistance to diseases and other influences for instance stress, drought, and nutrient deficiencies.

\section{Keywords}

Juniperus phoenicea, Green plant, Microbial isolates, Medicinal plants, Pigments and chlorophyll

\section{Introduction}

The main problems of dry and semi-arid rangelands are drought and lack of water that affect plant growth and development. Note that the majority of rangelands in the world are located in those regions the effect of drought stress on plants of these regions is of great importance [1]. Drought stress is the most an important environmental factor that reduces plant growth and, vegetation production $[2,3]$, an increase in temperature and a sharp decrease in the water available to plants are the most significant factors behind reducing vegetation cover [2].

Water scarcity is a constraining factor for plant growth, germination and seed development and lowers plant productivity over the world [4]. At present, Microorganisms have been used as a type of biological ferti-

\footnotetext{
Citation: Fakron A, Attitalla IH, Hassan MY, Dwivedi S (2021)The Importance of Microorganisms and Their Effects on Medicinal Plants and Their Various Applications. Int Arch Med Microbiol 3:011. doi. org/10.23937/2643-4008/1710011

Accepted: April 28, 2021: Published: April 30, 2021

Copyright: (c) 2021 Antonopoulos A, et al. This is an open-access article distributed under the terms of the Creative Commons Attribution License, which permits unrestricted use, distribution, and reproduction in any medium, provided the original author and source are credited.
} 
lizer as they work to repair and develop the soil ecosystem $[5,6]$. Also, bio-fertilizers provide the nutrients for plants, it also assists increase soil biodiversity [7]. The most important types of biological fertilizers used are bacteria, fungi and materials derived from their activity. This type of fertilizer is called yield-enhancing fertilizer $[5,6]$.

The mechanism of the plant growth-promoting bacteria has not been fully understood to increase the plant growth but the bacteria are capable of producing some growth-promoting hormones especially a variety of cytokinin, gibberellic acid and auxin, fixing nitrogen, and phosphorus [8]. Azotobacter spp. and Pseudomonas spp. are the most important bacteria that increase soil mineral elements, with the production of matters regulating growth and they affect development and yield of plants $[5,9]$. The use of bio-fertilizers such as nitrogen fixation bacteria of the genus Azotobacter and bacteria dissolving phosphate such as Pseudomonas, provide nutrients needed by the plant such as nitrogen and phosphorus and thus improves plant growth and yield in addition to increasing useful soil microorganisms' population [10]. It should note that the effect of growth-promoting bacteria depends on the yield of the host plant and soil environment furthermore, the inherent capabilities of bacteria [6]. However, growth-promoting bacteria play a great role in maintaining soil fertility and improving the plant growth and development, however, some concerns have also reported in some studies $[8,11]$. For example, cyanide production is a feature known to Pseudomonas [12]. Indeed cyanide, as an environmental controller, can increase growth, on the other hand, it hurts plant growth [12].

Also, the bacterium production of auxin in low concentration increased plant growth and at high concentration, it reduced plant growth $[8,13]$. Although growth-promoting bacteria are very effective in plant growth and development, certain bacterial species may specifically reduce growth and a negative role may occur under certain conditions. Therefore, it is essential to select the appropriate varieties to obtain maximum plant yield [6]. Avena sativa L. (family Gramineae) is a type of cereal grain grown for its seeds. It is suitable for human consumption and livestock feed [14]. Although this plant can grow in cool, wet weather and low fertility soils $[15,16]$, it is sensitive to drought stress [17].

\section{Materials}

\section{Plant material}

The Samples of Juniperus phoenicea were collected from the Al Jabal Al Akhdar region (Aslantah region), (sample 1 = plant with microbial inoculation (biofertilizer) growing naturally, sample 2 = plant without (microbial isolates).

\section{Chemicals}

1,1-Diphenylpicrylhydrazyl (DPPH), ethanol, methanol, and acetone provided by Sigma and Merck. Ascorbic Acid, Folin-Ciocalteu Reagent, Ferric Chloride, Monobasic Hydrogen Phosphate, Potassium ferricyanide, Dibasic Monobasic Phosphate, Trichloroacetic Acid, Sodium Carbonate, Anhydrous Sodium Sulfate and Pyrogallol.

\section{Results}

1. The morphological results are shown in Table 1 below. Sample (1) indicates the highest average value for plant height and stem diameter. They were $222.67 \mathrm{~cm}$ and $16.42 \mathrm{~cm}$, respectively.

2. The results acquired from this study as exposed in the Table 2 report that the healthy sample includes a high amount of chlorophyll A, chlorophyll B and carotenoids as compared with the semi-healthy sample and Sample disease (Figure 1).

\section{Growth characteristics of J. phoenicea}

The study samples separated into several varied trees, based on the exterior appearance with three replicates for each tree to reveal the quantitative and morphological differences.

Table 1: Growth from where plant height $(\mathrm{cm})$, stem diameter $(\mathrm{cm})$, and dry leaf weight $(\mathrm{mg})$ of J. phoenicea L. in EL-Gabal ELAhkdar area.

\begin{tabular}{|c|c|c|c|c|c|c|}
\hline \multirow{2}{*}{ Sample Name } & \multicolumn{2}{|c|}{ Plant height(cm) } & \multicolumn{2}{|c|}{ Stem diameter $(\mathrm{cm})$} & \multicolumn{2}{|c|}{ Leaf dry weight (mg) } \\
\hline & Mean & (SD) & Mean & (SD) & Mean & (SD) \\
\hline Healthy sample & 222.67 & $(21.35)$ & 16.42 & $(5.90)$ & 3.0234 & $(0.19)$ \\
\hline Semi healthy sample & 216.55 & $(17.93)$ & 11.22 & $(3.14)$ & 3.2058 & $(0.23)$ \\
\hline Sample sick & 214.23 & $(23.47)$ & 9.89 & $(2.05)$ & 3.8240 & $(0.11)$ \\
\hline
\end{tabular}

Table 2: Estimation of photosynthetic pigments of J. phoenicea L. leaves in EL-Gabal EL-Ahkdar area.

\begin{tabular}{|l|l|l|l|}
\hline Sample & $\begin{array}{l}\text { Chlorophyll A } \\
(\mathbf{m g} / \mathbf{m l})\end{array}$ & $\begin{array}{l}\text { Chlorophyll B } \\
\text { ( mg/ml) }\end{array}$ & $\begin{array}{l}\text { Carotenoids } \\
\text { ( mg/ml) }\end{array}$ \\
\hline Healthy sample & 5.7708 & 4.894 & 6.323 \\
\hline Semi healthy sample & 5.670 & 4.721 & 5.126 \\
\hline Sample sick & 4.346 & 2.915 & 3.503 \\
\hline
\end{tabular}


Healthy sample

Semi healthy sample

Sample sick

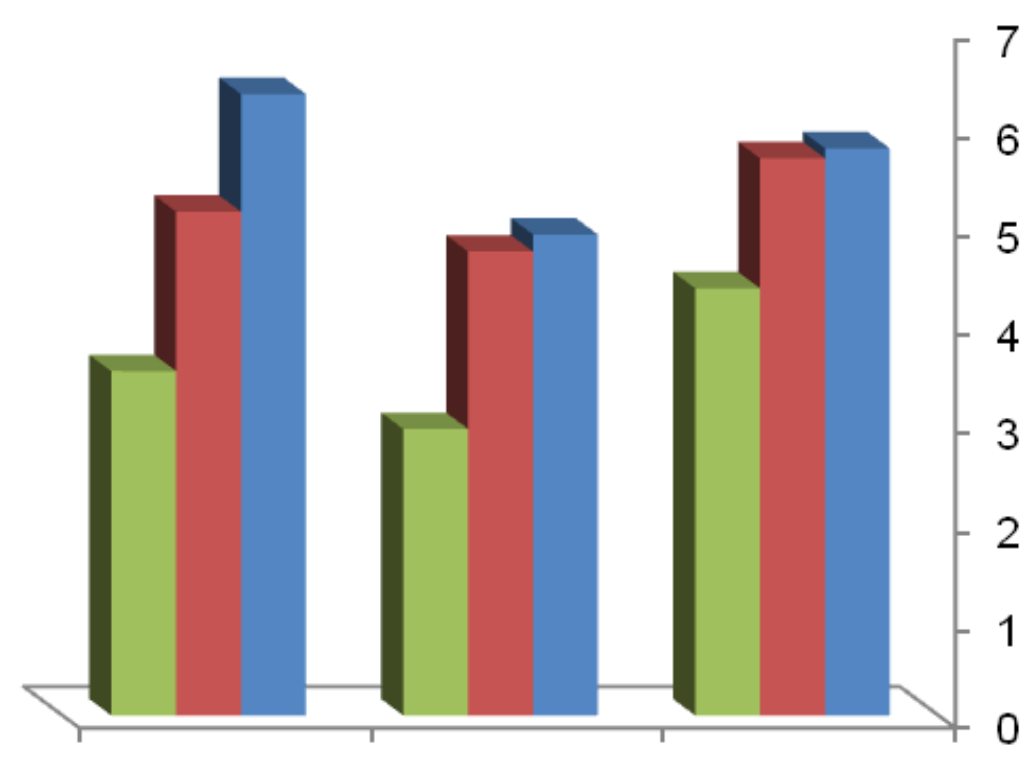

\section{Chlorophyll A Chlorophyll B Carotenoids}

Figure 1: Estimation of photosynthetic pigments of J. phoenicea L. leaves in EL-Gabal EL-Ahkdar area.

\section{Determination of pigments photosynthetic}

Photosynthetic pigments were obtained from the known fresh weight of leaves in $85 \%$ aqueous acetone to a specific concentration for spectroscopic measurements. Photosynthetic pigments (chlorophyll a, b and carotenoids) described by a spectrophotometric method [18]. The pigment extract measured against a blank of pure $85 \%$ aqueous acetone at three wavelengths 452.5 , 644 and $663 \mathrm{~nm}$. Taking into account, the dilution factor, it was possible to determine the concentration of chromosomal fractions (chlorophenol A, B and carotenoids) in $\mathrm{mg} / \mathrm{mL}$ utilizing the following equations:

$$
\begin{aligned}
& \text { Chlorophyll } \mathrm{a}=10.3 \mathrm{E}_{663}-0.918 \mathrm{E}_{644}=\mathrm{mg} / \mathrm{ml} \\
& \text { Chlorophyll } \mathrm{b}=19.7 \mathrm{E}_{644}-3.87 \mathrm{E}_{663}=\mathrm{mg} / \mathrm{ml} \\
& \text { Charotenoids }=4.2 \mathrm{E}_{452.5}\left\{\begin{array}{c}
0.0264 \mathrm{chl} . \mathrm{a} \\
+\quad=\mathrm{mg} / \mathrm{ml} \\
0.4260 \mathrm{chl} . \mathrm{b}
\end{array}\right.
\end{aligned}
$$

Finally, pigments parts calculated as $\mathrm{mg} / \mathrm{g}$ fresh matter.

\section{The Estimation of microbial number}

Nutrient agar medium: 23g of nutrient agar medium were dissolved in 1-litre $\mathrm{ml}$ distilled water and then sterilized by autoclaving at $15 \mathrm{lbs}$ pressure $\left(121^{\circ} \mathrm{C}\right)$ for 15 $\min$.

\section{Sample preparation}

Plant: Leaves (brown and green) were collected from Juniperus phoenicea. 2 grams of each part was put in a test tube containing $8 \mathrm{ml}$ of distilled water and shacked for 30 seconds. $1 \mathrm{ml}$ of the sample was put in a petri dish and then poured by nutrient agar medium under sterile conditions and incubated at $37.5^{\circ} \mathrm{C}$ for three days. Total number of microbial colonies of each plate was estimated.

Soil: Two samples collected from sifting soil. 1 gram of each sample from different sites (under the sieve and above the sieve) was added to a test tube containing $9 \mathrm{ml}$ of distilled water and shacked for 30 seconds. 1 $\mathrm{ml}$ of each sample was put in a petri dish and then set up the nutrient agar medium incubated at $37.5^{\circ} \mathrm{C}$ for three days. The total number of microbial colonies of each plate was estimated.

Pure culture: A single bacterial colony from each culture was streaked on nutrient agar medium and incubated at $37.5^{\circ} \mathrm{C}$ for three days.

Gram stain: Differential stains (Gram stain) conducted to confirm that the bacteria were gram-negative and rode shaped. Smears from single colonies grown on $\mathrm{EMB}$ at $37^{\circ} \mathrm{C}$ and $44.5^{\circ} \mathrm{C}$ were prepared and covered with Crystal violet for $1 \mathrm{~min}$ and then covered by lodine for 1 min to made CV-I complex after that, the decolourized agent (70\% ethanol) washed on the slide to remove the CV-I complex in the thin layer of peptidoglycan of gram-negative bacteria. Drops of safranin added for a half minute. The slide then washed in the distilled water and dried with filter paper after that the samples examined by the microscope using an oil immersion lens. In summary, gram-positive cells retain the dye and remain purple, Gram-negative cells did not retain the dye; they were colourless until counterstained with a red dye (pink cells).

Endospore staining: A thin film of a bacterial colony was made on a slide in a ring of distilled water. The film was air-dried and stained with malachite green for 4-5 minutes using a flame. The smear was rinsed quickly with water and stained with safranin solution for 30 se- 


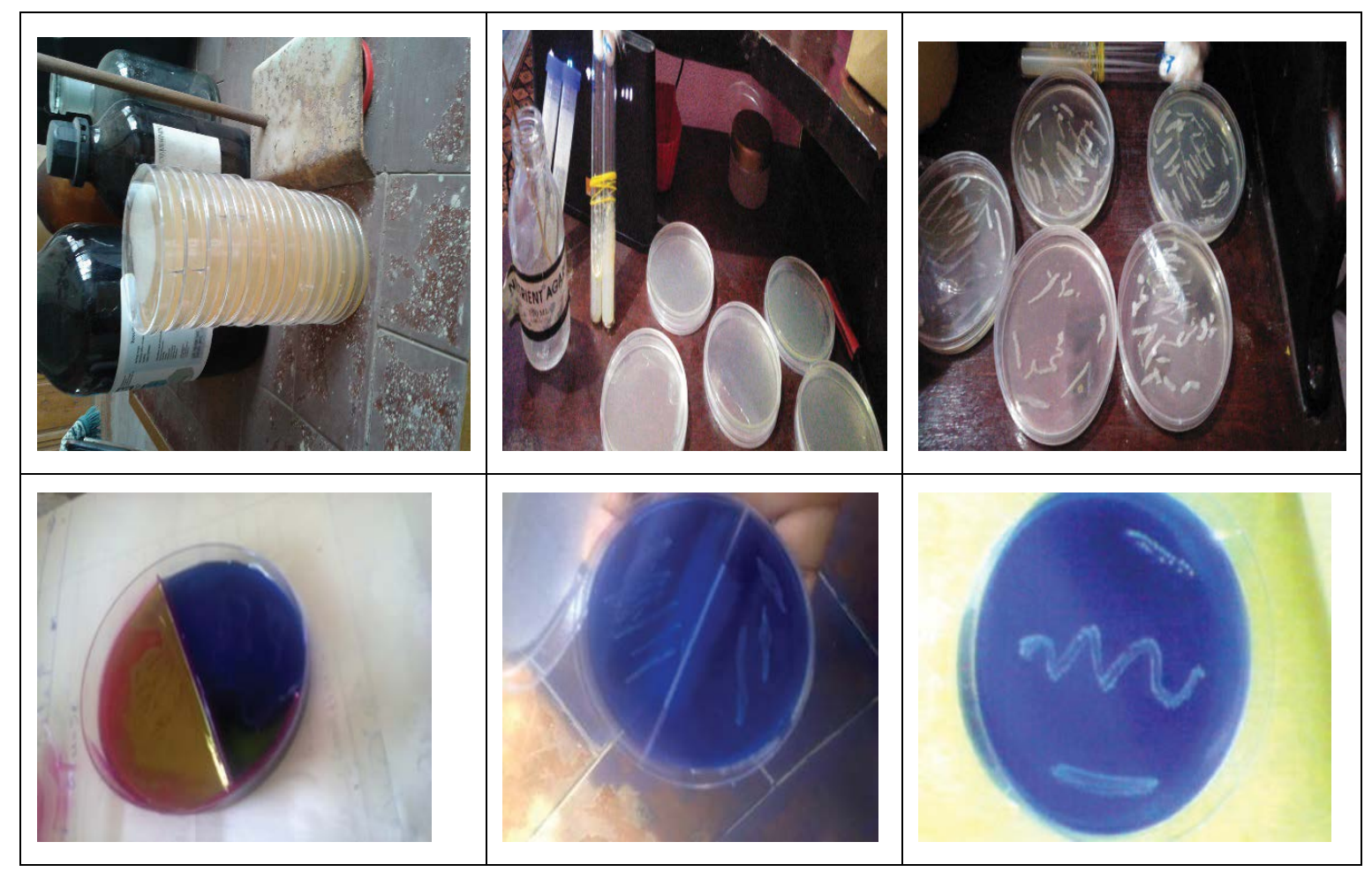

Figure 2: Microbial isolates.

conds. The slide was washed with water and allowed to dry. On microscopy, green spores appeared and cells were pink [19].

Motility test: The test was applied to identify the motile and immobile bacteria using a suspension. A little immersion oil was applied around the edge of the slide and then using a wire loop a small ring of culture was transferred to a clean dry covered slip. The slide was then turned over the cap so that the drop was in the centre of the socket and the slide was pressed down gently and lightly so that the oil held the cap in place. The slide was turned over quickly and smoothly and the farm drop was placed in a hanging drop shape, and the preparation was quickly checked. It is important to identify between Brownian motion (the continuous excitation of a very small particle suspended in a liquid called unbalanced effects with the particles of the surrounding fluid) or one-way drift due to the slice being slightly tilted and true motion [19] (Figure 2).

\section{Conclusion}

The results indicated that individual growth-promoting bacteria had a higher effect on increased plant growth, photosynthesis and nutrient absorption in the root of Juniperus phoenicea, compared to the combined use of growth-promoting bacteria. Moreover, it was observed that the growth-promoting bacteria under irrigation conditions had a role in mitigating the effects of drought stress. The results of the study concluded that growth-promoting bacteria can be used in the restoration and improvement of pastures, but it must be taken into account that the effect of bio-fertilizers de- pends on the type of plant, climate and soil condition. However, an important question is to what extent root bacteria can enhance plant resistance to the effects of drought. This matter needs more research to know the suitable strains for each region and plant, Given that growth-promoting root bacteria, include a wide range of soil microorganisms. Therefore, a more comprehensive and rigorous survey and study in this area are recommended. The current study was divided into two types of experiments, one of which is using microbial isolates as an important type of fertilization and the other without adding microorganism. Since drought stress is one of the most important factors causing plant growth decline, the present study was conducted to study the effect of growth-promoting bacteria on growth and photopigments under drought stress Juniperus phoenicea. To investigate the effect of microorganisms on root nutrient uptake in Juniperus phoenicea under drought stress. The role and efficiency of microorganisms in providing plants with the nutrients it needs and increasing growth.

\section{References}

1. Esfahan ZE, Azarnivand H (2012) Effect of water stress on seed germination of Agropyron elongatum, Agropyron desertourm and Secale montanum. Desert 17: 249-253.

2. Nazar R, Umar S, Khan N, Sareer O (2015) Salicylic acid supplementation improves photosynthesis and growth in mustard through changes in proline accumulation and ethylene formation under drought stress. South African Journal of Botany 98: 84-94.

3. Sadeghi $H$, Rostami $L$ (2016) Evaluating the physiological and hormonal responses of caper plant (Capparis spinosa) subjected to drought and salinity. Desert 21: 49-55. 
4. Yan M (2015) Seed priming stimulate germination and early seedling growth of Chinese cabbage under drought stress. South African Journal of Botany 99: 88-92.

5. Zahir A, Arshad M, Frankenberger W (2004) Plant growth promoting rhizobacteria: Applications and perspectives in agriculture. Advances in Agronomy 81: 97-168.

6. Nadeem SM, Ahmad M, Zahir Z, Javaid A, Ashraf M (2014) The role of mycorrhizae and plant growth promoting rhizobacteria (PGPR) in improving crop productivity under stressful environments. Biotechnology Advances 32: 429-448.

7. Delshadi $S$ (2015) Effects of plant growth promoting rhizobacteria on seed germination and growth of Bromus tomentellus, Onobrychis sativa and Avena sativa in drought stress.

8. Vacheron J, Desbrosses G, Bouffaud M, Touraine B, Moenne-Loccoz Y, et al. (2013) Plant growth promoting rhizobacteria and root system functioning. Frontiers in Plant Science 4: 1-19.

9. Hayat R, Ali S, Amara U, Khalid R, Ahmed I (2010) Soil beneficial bacteria and their role in plant growth promotion: a review. Annals of Microbiology 60: 579-598.

10. Arancon N, Edwardy CA, Bierman P, Welch C, Metzgar JD (2004) Influences of vermicomposts on field strawberries: Effect on growth and yields. Bioresource Technology 93: 145-153.

11. Saharan BS, Nehra V (2011) Plant growth promoting rhizobacteria: A critical review. Life Science and Medical Research 21: 1-30.
12. Martínez-Viveros O, Jorquera MA, Crowley DE, Gajardo G, Mora ML (2010) Mechanisms and practical considerations involved in plant growth promotion by rhizobacteria. Journal of Soil Science Plant Nutrition 10: 293-319.

13. Patten C, Glick B (2002) Role of Pseudomonas putida indole acetic acid in development of the host plant root system. Applied and Environmental Microbiology 68: 3795-3801.

14. Achleitner A, Tinker NA, Zechner E, Buerstmayr H (2008) Genetic diversity among oat varieties of worldwide origin and associations of AFLP markers with quantitative. Theor Appl Genet 117: 1041-1053.

15. Ren CZ, Ma BL, Burrows V, Zhou J, Hu YG, et al. (2007) Evaluation of early mature naked oat varieties as a summer-seeded crop in dryland Northern climate regions. Field Crop Res 103: 248-254.

16. Buerstmayr H, Krenn N, Stephan U, Grausgruber H, Zechner E (2007) Agronomic performance and quality of oat (Avena sativa L.) genotypes of worldwide origin produced under Central European growing conditions. Field Crops Res 101: 341-351.

17. Frey W, Probst $P$ (1986) A synopsis of the vegetation of Iran. In: Kiirschner $\mathrm{H}$, Contributions to the Vegetation of Southwest Asia. Dr. Ludwig Reichert Verlag, 9-43.

18. Metzner H, Rau H, Senger H (1965) Untersuchungen zur Synchronisierbarkeit einzelner Pigmentmangel Mutanten von Chlorella. Planta 65: 186-194.

19. Abualdahab M Kamal, Gorani M Abdalgader (1983) Bacteria, Eltamareen Almamalyia Alasaseeya 86-87, 107-108. 